\title{
Successful management of a young patient with yolk sac tumour
}

\author{
Meena N. Satia, Vibha More, Manali P. Shilotri*
}

Department of Obstetrics and Gynecology, Seth G.S.M.C and K.E.M Hospital, Mumbai, Maharashtra, India

Received: 25 October 2016

Accepted: 23 November 2016

*Correspondence:

Dr. Manali P. Shilotri,

E-mail: manali.shilotri@gmail.com

Copyright: () the author(s), publisher and licensee Medip Academy. This is an open-access article distributed under the terms of the Creative Commons Attribution Non-Commercial License, which permits unrestricted non-commercial use, distribution, and reproduction in any medium, provided the original work is properly cited.

\section{ABSTRACT}

Yolk sac tumours, synonymous with endodermal sinus tumours, are rare, malignant germ cell neoplasms occurring usually in gonads. Yolk sac tumours are more commonly seen in patients of early age group, the median age being 18 years. We report a case of a yolk sac tumour of the ovary in a 21 year old female, managed by surgery and chemotherapy.

Keywords: Endodermal sinus tumour, Germ cell tumour, Yolk sac tumour

\section{INTRODUCTION}

Yolk sac tumours are non-dysgerminomatous germ cell tumours. They are rare, rapidly growing, with extensive intra-abdominal spread and have a poor prognosis. ${ }^{1}$ They are seen in early adulthood between 18-30 years of age. ${ }^{2}$ They are always unilateral. The standard treatment is complete surgical excision followed by chemotherapy since they are highly chemo-sensitive. As they are unilateral in all cases and occur in young patients, unilateral salpingo-oophorectomy can be performed to preserve fertility. First line chemotherapeutic agents include bleomycin, etoposide and cisplatin. Vigilant follow-up of these patients with monitoring of serum alpha fetoprotein levels (AFP) and annual pelvic ultrasonography is the usual recommendation for patients with yolk sac tumours.

\section{CASE REPORT}

21 years old nulligravida, married since 1 year, came to our gynaecology outpatient department with complaints of pain in abdomen along with a lump in the abdomen since 6 months. On examination, vital parameters were normal. On abdominal examination, a mass of 18 weeks size, firm in consistency, arising from the pelvis was palpable. On vaginal examination the size of the uterus was normal and it was retroverted. There was a mobile mass of 18 weeks size felt in the posterior and left fornix. Per rectal examination showed that the mucosa was free. Ultrasonography was suggestive of a left ovarian large echogenic mass with cystic areas of 11.4 X 9.9 X $11.8 \mathrm{~cm}$ with increased vascularity. The uterus was of $6.8 \mathrm{X} 4.2 \mathrm{X}$ $3.6 \mathrm{~cm}$ size with an endometrial thickens of $9 \mathrm{~mm}$. There was no significant lymphadenopathy. Computed tomography (CT) scan was suggestive of mild ascites with a left ovarian mass which was partly solid partly cystic with multiple septations. The fat planes between the mass and the rectosigmoid were well maintained. Alpha fetoprotein (AFP) was markedly elevated i.e. $11,404 \mathrm{ng} / \mathrm{ml}$, lactate dehydrogenase (LDH) was 669 U/L, CA-125 was $206 \mathrm{U} / \mathrm{L}$, carcinoembryonic antigen (CEA) $1.70 \mathrm{ng} / \mathrm{ml}, \beta$-hCG less than $0.13 \mathrm{mIU} / \mathrm{ml}$. Her complete blood count, liver function test, renal function test, chest X ray and electrocardiogram were normal. In view of elevated AFP and LDH a clinical impression of a left ovarian yolk sac tumour was made and a decision of exploratory laparotomy with left salpingo-oophorectomy with omentectomy was taken in view of her young age and desire to preserve fertility. Intra-operatively a left ovarian solid-cystic mass of $10 \times 10 \mathrm{~cm}$ was seen with torsion and moderate amount of ascites was observed. Uterus, right ovary and both fallopian tubes were normal. Ascitic fluid for cytology and a frozen section of the mass were sent. The frozen section was suggestive of a yolk sac tumour. A left salpingo-oophorectomy with 
omentectomy was performed (Figures 1,2). Detailed microscopic evaluation was suggestive of yolk sac tumour (Figures 3, 4). On immunohistochemistry the tumour cells were focally positive for glypican 3, while negative for epithelial membrane antigen (EMA), CD30, MIC2, calretinin and inhibin thus ruling out sex cord stromal cells and epithelial cell tumours and clinching the diagnosis of a yolk sac tumour. The opinion of an oncologist was taken and the patient was advised chemotherapy. She received three cycles of BEP therapy i.e. bleomycin, etoposide and cisplatin. She was monitored with serial complete blood counts, liver function tests, renal function tests, serum alpha fetoprotein levels and ultrasonography. After the first cycle of chemotherapy, alpha fetoprotein fell to 1937.92 $\mathrm{ng} / \mathrm{ml}$ and CA-125 fell to $157 \mathrm{U} / \mathrm{L}$. After completion of three cycles of BEP chemotherapy, the level of serum alpha fetoprotein was $4.41 \mathrm{ng} / \mathrm{ml}$ and CA-125 was 1.7 U/L i.e. within normal limits. Postoperative follow up and monitoring was done by ultrasonography and serum alpha fetoprotein levels, which showed a satisfactory decreasing trend.

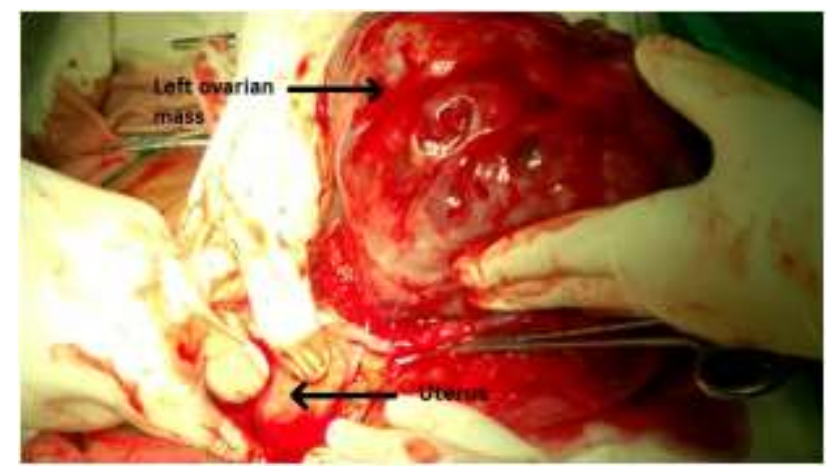

Figure 1: Intraoperative picture showing a left solidcystic ovarian mass of $10 \times 10 \mathrm{~cm}$ with normal uterus and left fallopian tube.

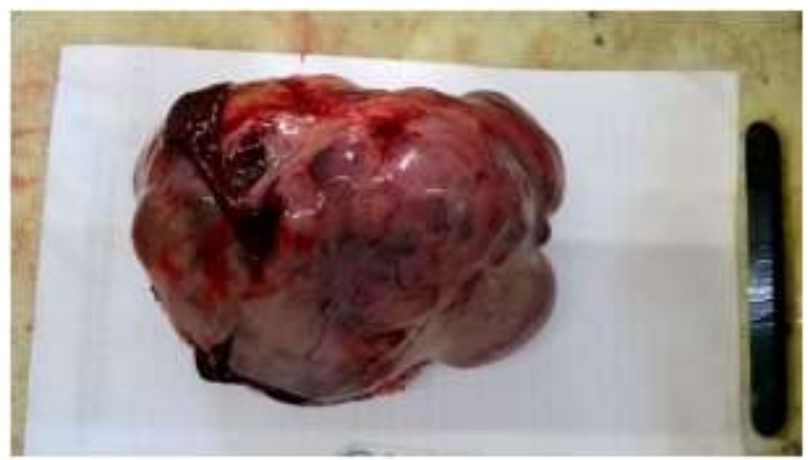

Figure 2: Gross appearance of left ovarian yolk sac tumour.

\section{DISCUSSION}

Germ cell tumours account for $15-20 \%$ of all ovarian tumours. ${ }^{3}$ Germ cells are totipotent and therefore a wide variety of neoplasms can develop from them. Germ cell tumours are classified as dysgerminomas and nondysgerminomas. Yolk sac tumours, also known as endodermal sinus tumours are a sub-type of the nondysgerminomas. They are the second most common germ cell tumour. The pathogenesis of a yolk sac tumour is unknown. From the fourth to sixth week of embryogenesis, normally, germ cells migrate through the dorsal mesentery in the midline. Germ cell tumours arise from remnants of the tissue anywhere along the migration course. It is suggested that yolk sac tumours arise from the local transformation of such misplaced primordial germ cells. Yolk sac tumours are malignant, rapidly growing tumours with a poor prognosis. Patients present with abdominal pain in $70 \%$ of cases or asymptomatic abdominal mass in $10 \%{ }^{4}$ They metastasize haematogeneously. Radiological diagnosis is difficult as yolk sac tumours do not have any specific characteristics on ultrasonography, magnetic resonance imaging (MRI) or computed tomography (CT). They are usually cystic, with signs of increased vascularity and areas of haemorrhage.

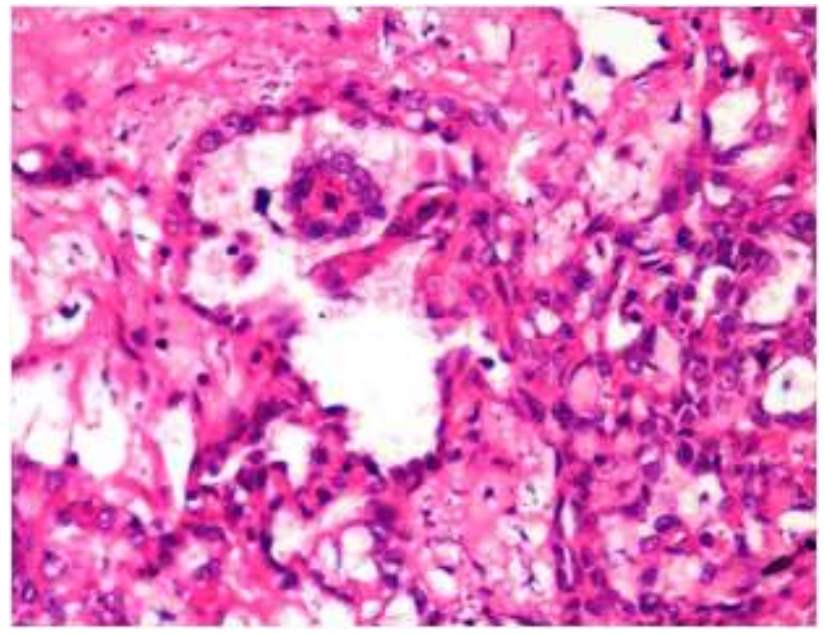

Figure 3: Microscopic picture of ovarian yolk sac tumour showing Schiller-Duval body.

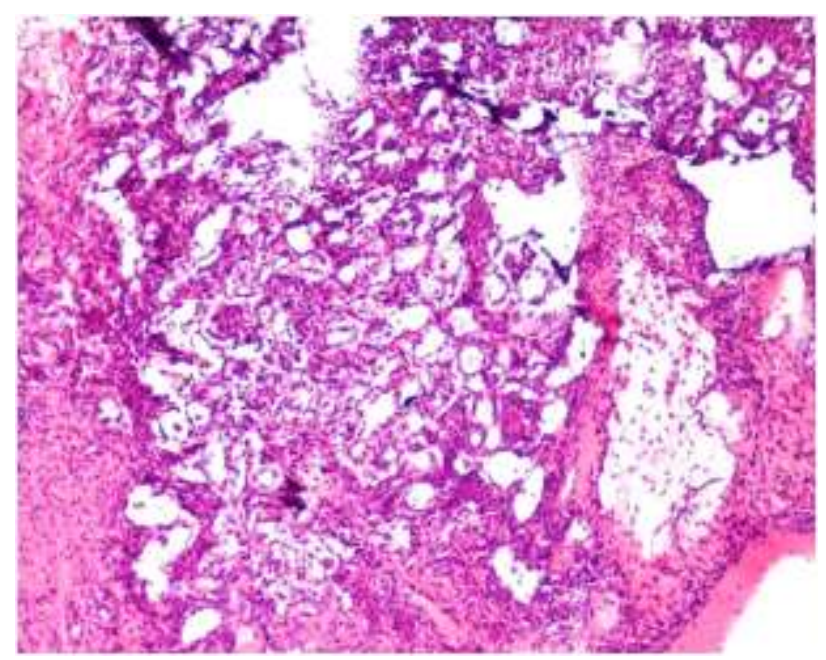

Figure 4: Microscopic picture of ovarian yolk sac tumour. 
Doppler ultrasonography shows multiple small arterioles with low resistive index (RI). Yolk sac tumours are always unilateral; therefore biopsy of the contralateral ovary is not required. Surgical treatment comprises of unilateral salpingo-oophorectomy with omentectomy as a fertility sparing measure. Bilateral salpingooophorectomy with or without hysterectomy does not seem to improve survival. ${ }^{5}$ The characteristic picture on microscopy is the Schiller-Duval body which resembles a glomerulus. It appears as a central vessel surrounded by tumour cells which in turn is contained in a space lined by flattened tumour cells. This structure is seen in only $20 \%$ of yolk sac tumours and is hence not essential for diagnosis. A yolk sac tumour produces alpha fetoprotein, which can be stained using immunohistochemistry in the cells and can also be detected in the serum. AFP levels are directly proportional to the extent of the tumour. Alpha fetoprotein level is not only important for diagnosis but is also helpful for checking the effectiveness of therapy, for follow up of patients and for detection of a recurrence. Standard therapy includes adjuvant chemotherapy consisting of bleomycin, etoposide and cisplatin for all patients. ${ }^{6}$ Serum alpha fetoprotein levels are repeated after each cycle of chemotherapy, soon after the end of the treatment and during the two years after the end of the treatment. ${ }^{7}$ In case of conservative treatment, an annual pelvic ultrasonography is necessary, to screen for contralateral recurrence. A patient with stage I disease at the time of initial presentation, who takes less than 42 days in the post-operative period to AFP normalisation has factors associated with a good prognosis.

\section{CONCLUSION}

Yolk sac tumours are an important type of ovarian malignancy in the young and reproductive age group women. Although they were previously thought to have a very poor prognosis, in the present times, surgery with adjuvant chemotherapy has resulted in a reasonably favourable outcome. With the option of fertility preserving surgical therapy and diligent follow-up, affected women can now look forward to a healthy and normal reproductive life.

\section{ACKNOWLEDGEMENTS}

We acknowledge the faculty of the Department of Pathology, Seth G.S.M.C and K.E.M Hospital, Mumbai, Maharashtra, India for providing pictures of the histopathological slides of the specimen.

Funding: No funding sources

Conflict of interest: None declared

Ethical approval: Not required

\section{REFERENCES}

1. Telium G. Endodermal sinus tumors of the ovary and testis. Comparative morphogenesis of the so-called Mesonephroma ovarii (Schiller) and extra embryonic (yolk sac-allantoic) structures of the rat's placenta. Cancer. 1959;12:1092-05.

2. Bidus M, Zahn C, Rose G. Germ Cell, Stromal, and other Ovarian Tumors. In: DiSaia PJ, Creasman WT. eds. Clinical Gynecologic Oncology. 7th ed. Philadelphia: Mosby; 2007:369-395.

3. Kumar V, Cotran R, Robbins S. Robbins Basic Pathology. 7th ed. Philadelphia, PA: Saunders; 2003:664.

4. Imai A, Furui T, Tamaya T. Gynecologic tumors and symptoms in childhood and adolescence: 10 years experience. Int J Gynaecol Obstet. 1994;55:S62-72.

5. Low J, Ilancheran A, Ng J. Malignant ovarian germ-cell tumours. Best Practice and Research Clinical Obstetrics and Gynaecology. 2012;26(3):347-55.

6. Kang H, Kim TJ, Kim WY, Choi CH, Lee JW, Kim $\mathrm{BG}$, et al. Outcome and reproductive function after cumulative high-dose combination chemotherapy with bleomycin, etoposide and cisplatin (BEP) for patients with ovarian endodermal sinus tumor. Gynecol Oncol. 2008;111(1):106-10.

7. De La Motte Rouge T, Pautier P, Duvillard P, Rey A, Morice P, Haie-Meder C, et al. Survival and reproductive function of 52 women treated with surgery and bleomycin, etoposide, cisplatin (BEP) chemotherapy for ovarian yolk sac tumor. Ann Oncol. 2008;19(8):1435-41.

Cite this article as: Satia MN, More V, Shilotri MP. Successful management of a young patient with yolk sac tumour. Int J Reprod Contracept Obstet Gynecol 2017;6:323-5. 